\title{
The Effects and Level of Catalase Enzyme Activity in Different Species of Aquatic Macrophytes and Their Families in Two Different Locations in Niger Delta, (Ikpoba River in Benin-City and Ethiope River in Abraka), Nigeria
}

\author{
Vincent Oyareme ${ }^{1 *}$, Eunice I. 0. Osaji ${ }^{2}$ \\ ${ }^{1}$ Environmental (Option) in SAES, University of the Gambia (UTG), Banjul, Gambia \\ ${ }^{2}$ Department of Physical \& Health Education, Faculty of Education, Delta State University, Abraka, Delta State, Nigeria \\ Email: *voyareme@utg.edu.gm
}

\begin{abstract}
How to cite this paper: Oyareme, V. and Osaji, E.I.O. (2021) The Effects and Level of Catalase Enzyme Activity in Different Species of Aquatic Macrophytes and Their Families in Two Different Locations in Niger Delta, (Ikpoba River in Benin-City and Ethiope River in Abraka), Nigeria. Open Access Library Journal, 8: e7368. https://doi.org/10.4236/oalib.1107368
\end{abstract}

Received: March 30, 2021

Accepted: April 27, 2021

Published: April 30, 2021

Copyright $\odot 2021$ by author(s) and Open Access Library Inc.

This work is licensed under the Creative Commons Attribution International License (CC BY 4.0).

http://creativecommons.org/licenses/by/4.0/ c) (i) Open Access

\begin{abstract}
This study was carried out to analyze the levels of oxygen evolved in catalase activity during hydrogen peroxide decomposition reaction in species of different aquatic macrophytes and their selected families, Pontederiaceae, Araceae, Lemnaceae, Ceratophyllaceae, Azollaceae, Nymphaeaceae in two different Rivers in Delta and Edo State. Hydrogen peroxide is formed as a toxic waste product of metabolism which is quickly converted into other less dangerous chemicals. It is an important signal molecule involved in plant development and environmental responses. The enzyme catalase is frequently used to rapidly catalyze the decomposition of hydrogen peroxide into a harmless molecule of oxygen and water. Anthropogenic activities of excess nitrogen and phosphorus nutrient enrichment into water body proliferation result in eutrophication, which most species of aquatic microphytes can use to control them. The catalase levels in species of Eichhornia crassipes followed by Eichhornia natans in Pontederiacea family recorded the highest in their leaves $(24.83 \pm 0.29)$ in Ethiope River and $(24.20 \pm 0.10)$ in Ikpoba River respectively among the aquatic macrophytes studied. Those species under the family Nymphaeaceae had $(23.73 \pm 0.64)$ as in water lily in their leave tissues in Ethiope River, followed by the family Ceratophyllaceae which had (20.33 \pm $0.58)$ in Ikpoba River, Edo State. The lowest catalase activity was recorded in the roots of Azolla africana and Nymphaea lotus (12.00 \pm 0.05$)$ and (12.30 \pm
\end{abstract}


0.10) in Ethiope and Ikpoba River. Catalase enzymes present in these species of aquatic macrophytes are useful in commercial cleaning operations in bioremediation for aquatic and terrestrial ecosystems.

\section{Subject Areas}

Environmental Sciences

\section{Keywords}

Catalase Enzyme in Leaf and Root Tissues of Aquatic Macrophytes, Hydrogen Peroxide, Water and Oxygen

\section{Introduction}

Catalase is a substance that protects cells from the damage caused by free radicals unstable molecules made by the process of oxidation during normal metabolism that catalyzes the conversion of hydrogen peroxide to two molecules of water and a molecule of oxygen. Structurally, catalases can be divided into three classes thus, mono-functional catalase or typical catalase, catalase-peroxidase, and pseudo catalase or Maganese-catalas [1]. Agriculturally, processing of food, textile and several industrial applications make use of catalase to remove hydrogen peroxide that is used for bleaching and sterilization. Catalase is an antioxidant enzyme found in living organisms that changes hydrogen peroxide to water and oxygen molecule. Hydrogen peroxide is formed as a toxic waste product of metabolism. It must be quickly converted into other less dangerous chemicals. To manage this problem, the enzyme catalase is frequently used to rapidly catalyze the decomposition of hydrogen peroxide into harmless oxygen and water. In aerobic cells, free radicals are constantly produced mostly as reactive oxygen species (ROS). Once produced, free radicals are moved by antioxidant defenses including the enzyme catalase, glutathione, peroxidase and superoxide dismutase (SOD). Reactive oxygen species including nitric oxide and related species commonly exert a series of useful physiological effects [2]. However, the balance between pro-oxidant and antioxidant defenses in favor of pro-oxidants results in oxidative stress, this results in damage to lipids, proteins and nucleic acids, in combination with primary factors, free radicals are involved in the cause of hundreds of diseases. Catalase researcher studied mice genetically engineered to produce a human antioxidant enzyme which lived longer than normal mice. This pointed to the possibility that antioxidants can counteract the effects of aging and disease. Chemicals known as free radicals, damage cells by generating a reaction called oxidation, the same process that causes metal to rust, Antioxidant also interferes with these chemical reactions. Genetically engineered mice that made extra amounts of catalase were precisely designed to produce extra amounts of catalase in certain areas of the study, the cell's cytoplasm, the nuc- 
leus, where DNA is stored and the mitochondria, the cell's power plant and also the place where some DNA is found. The mice that made more catalase in the mitochondria lived about twenty percent longer about five months. The mice with more catalase levels in the nucleus and cytoplasm lived only a little longer than normal mice. They also had healthier heart muscle tissue, indicating the catalase helped protect from age-related heart problems seen in normal mice [3]. One catalase molecule can convert millions of molecules of hydrogen peroxide to water and oxygen per second; hence catalase is a long tetramer of four polypeptide chains each over five hundred amino acids (500aa), but much lower affinity than peroxidase (APx), glutathione/thioredoxine peroxidase (GPX), glutathione S-transferases (GST) and peroxiredoxins (PRX), which in turns have kinetic movement values below $100 \mu \mathrm{M}$. Although it is very difficult to determine precise kinetic characteristics for catalase (CAT) as estimated by the apparent kinetic movement for hydrogen peroxide is in the range of $40-600 \mathrm{mM}$ [4] [5]. The four groups of iron porphyrin heme contained to allow the enzyme to react with hydrogen peroxide. The optimum $\mathrm{pH}$ for human catalase is approximately seven (7), the reaction rate does not change appreciably at $\mathrm{pH}$ scales between 6.80 and 7.50. In humans, catalase deficiency has recently been implicated in graying of hair, another study and interesting observation are that aging of human cells can be alleviated by engineering improved peroxisomal impact of catalase [6]. Several studies also showed the implication of peroxisomes and Reactive Oxygen Species (ROS) in senescence in plants. The optimum temperature also varies by species of plant in aquatic macrophytes [7]. Catalase is a highly efficient, selective, and specific biological catalyst, which makes them extremely popular in various bioprocesses. Ubiquitously, Catalase is one of the common enzymes found in all living organisms. It has several uses including food processing, pharmaceutical and cosmetics, textiles, paper production, medical fields and bioremediation [8]. The harsh operating condition of catalase is limited due to the inability to withstand the industrial processes, since high detergent concentrations and high organic solvent concentrations could result in extreme $\mathrm{pH}$ values which originally, considered a little or no importance in biology, then subsequently, as rapidly metabolized by-products in reactions such as chloroplast pseudocyclic electron transport also called the water-water cycle [9]. ROS gained importance during the 1980s as a key player in both abiotic and biotic stress responses. Until ten years ago, the predominant view on ROS was that they were toxic molecules that cause damage, leading to the notion that cross-resistance to stress could be engineered in plants by enhancing antioxidative capacity [10].

The aim of this study is to analyze the levels of oxygen evolved in catalase activity during hydrogen peroxide decomposition reaction in species of different aquatic macrophytes and their selected families, Pontederiaceae, Araceae, Lemnaceae, Ceratophyllaceae, Azollaceae, Nymphaeaceae in two different Rivers in Delta and Edo State. 


\section{Materials and Methods}

This study was carried out in Ikpoba River located in Benin City, Edo State, which has a latitude of $6.3350^{\circ} \mathrm{N}$ and Longitude of $5.6037^{\circ} \mathrm{E}$ and Ethiope River located in Abraka, Delta state, which has Latitude of $5.7894^{\circ} \mathrm{N}$ and Longitude of $6.1023^{\circ} \mathrm{E}$ both in Nigeria.

\subsection{Climate}

The climate of the study area is that of tropical rainforest with distinct wet and dry seasons. The wet season is characterized by prolonged rainfall which extends from April to October, while the dry season is characterized by a hot dry weather. This dry season extends from November to March including the harmattan period. The mean annual rainfall ranges from $2000 \mathrm{~mm}$ (inland) to over 4000 $\mathrm{mm}$ at the coast. The average precipitation in the area is estimated to be about $240 \mathrm{~cm}$ per annum.

\subsection{Geology}

Geologically Edo State is in Niger Delta, which is characterized by Sedimentary rocks. Lithostratigraphically, these rocks are divided into the oldest Akata Formation (Paleocene), the Agbada Formation (Eocene) and the Youngest Benin Formation (Miocene to Recent). The formation of the so-called proto-Niger Delta occurred during the second depositional cycle (Campanian-Maastrichtian) of the southern Nigerian basin.

\subsection{Sample Preparation/Extraction}

Fresh leaf and root tissues were blended/ground with pestle and mortar. About 4 $\mathrm{g}$ of ground tissue was introduced into a test tube, $15 \mathrm{~cm}$ long by $1.2 \mathrm{~cm}$ diameter. The mouth of the tube was fitted with a rubber bung carrying a pressure-releasing valve of about $7.50 \mathrm{~cm}$, a delivery tube (glass and rubber tubing's), and a $21 \mathrm{ml}$ burette with a tap.

The delivery tube was passed through tap water in a trough or basin and directed into the mouth of an inverted water-filled measuring cylinder. The entire assembly was positioned by appropriate clamping on retort stand of the experimental setup.

The burette was filled with six percent $(6 \%)$ of hydrogen peroxide $\left(\mathrm{H}_{2} \mathrm{O}_{2}\right)$. Through preliminary experiments to standardize the estimation for comparison, $6 \mathrm{mls}$ of hydrogen peroxide was found to exhaust all tissue reactions with the peroxide in that range of tissue weight taken. All experiments were conducted at room temperature.

When the set-up was ready, the pressure control valve was closed using the metal clip, and the burette tap was opened carefully to run $6 \mathrm{mls}$ of hydrogen peroxide into the ground tissue in the tube, with careful shaking to ensure thorough mixing. At the same time, the delivery tube was watched to ensure that any gas evolved from the reaction mixture was properly directed to bubble into 
the inverted cylinder. The volume of the gas released (if any) was read directly on the cylinder. The tube was then disconnected and washed while the measuring cylinder was refilled and fitted back. The clip of the pressure valve was opened; the burette refilled with hydrogen peroxide, and fresh ground tissue of the known weight of $4 \mathrm{~g}$ was put in the test tube. The gadget was ready for a re-run of the experiment when the rubber bung with the attachments was fitted back on the test-tube. For each tissue, three replicates of the estimations were carried out [11]. The number of different types of plant species under aquatic macrophytes investigated was known to be 31 . This number of plant species of aquatic macrophytes known, belongs to different taxonomic families such as Pontederiaceae, Nymphaceae, Azollaceae, Lemniaceae Araceae and Ceratophylliaceae. In each family, 3 to 8 genera were used and the total numbers of species of aquatic macrophytes investigated were 31 species.

\subsection{Statistical Analysis}

Basic statistical measurement of central tendency and dispersion was used to characterize stations in terms of leaf and root tissue values of catalase in species of aquatic macrophytes. Inter-stations comparisons were carried out to test for significant difference in the levels of catalase enzyme of selected species of aquatic macrophytes using a non-parametric analysis of variance (ANOVA), for each plant family, species of aquatic macrophyte was performed separately using variable such as station. The significant difference among the station means values were determined using kruskal Wallis test (KWT) a Non-Parametric Analysis of Variance, as a single factor ANOVA by Ranks [12].

\section{Results and Discussion}

The results of the analysis of leaf and root tissue of aquatic macrophytes are shown in Table 1 and Table 2. The result showed the effects and levels of catalase enzyme in both leaf and root tissues of aquatic macrophytes species mostly found in Ethiope River and Ikpoba River in Nigeria. Their values are expressed as mean $\pm \mathrm{SD}$ and the results are means of three replicates. A new element formed in the presented study is a means used in determining the presence of oxygen in both leaf and root tissues of aquatic macrophytes species respectively.

The values of Eichhornia crassipes in leaf tissue of both stations 1 and 2 ranged from (20.70 - $25.00 \mathrm{ml})$. The highest value of oxygen was recorded in the leaf tissue of Eichhornia crassipes having $24 \pm 0.29 \mathrm{ml}$ in Ethiope River, and lower value was recorded in Ikpoba River, which had $20.83 \pm 0.12 \mathrm{ml}$. Eichhornia crassipes and Eichhornia natan are species commonly known as water hyacinth in the family Pontederiaceae. Echhornia natan in Ethiope River and Ikpoba River had mean values of $23.67 \pm 0.58 \mathrm{ml}, 24.20 \pm 0.10 \mathrm{ml}$ respectively (Table 1 ). The values of oxygen recorded in root tissue of both species in Table 2, ranges from $(14.78-16.00 \mathrm{ml}), 15.80 \pm 0.20 \mathrm{ml}$ and $14.78 \pm 0.06 \mathrm{ml}$ for Eichhornia crassipes in the two stations, Eichhornia natan had mean root value of $16.67 \pm$ 
$0.58 \mathrm{ml}$ and $16.70 \pm 0.08 \mathrm{ml}$ respectively in Ethiope and Ikpoa River. In some occasions, dissolved oxygen concentration reduced below normal range because of accumulation of toxic substance which may be due to degradation by other enzyme proteases during phytoremediation [13] [14]. Studies had revealed that catalase (CAT) activity showed a differential response under heavy metal stress of lead $(\mathrm{Pb})$ toxicity in an aquatic environment. In Vicia faba, in Fabaceae family increased activity of catalase (CAT) has been reported according to [15]. Study also showed that CAT acts as a sink indispensable for stress in hydrogen peroxide $\left(\mathrm{H}_{2} \mathrm{O}_{2}\right)$ and $\mathrm{C}_{3}$ plants because CAT-deficient plant species show increased susceptibility to stress as well as bioremediation application in the aquatic environment [16].

Table 1. Shows the comparative volume of oxygen $(\mathrm{ml})$ evolved from hydrogen peroxide by unit weight of leave tissue from different species of aquatic macrophytes.

\begin{tabular}{ccccccc}
\hline $\begin{array}{c}\text { Species of aquatic } \\
\text { macrophytes. }\end{array}$ & $\begin{array}{c}\text { Ethiope River } \\
\text { (station A) }\end{array}$ & $\begin{array}{c}\text { Range } \\
\text { Min-max. }\end{array}$ & $\begin{array}{c}\text { CV } \\
\%\end{array}$ & $\begin{array}{c}\text { Ikpoba River } \\
\text { (Station B) }\end{array}$ & $\begin{array}{c}\text { Range } \\
\text { Min.-Max. }\end{array}$ & $\begin{array}{c}\text { CV } \\
\%\end{array}$ \\
\hline Eichhornia crassipes & $24.83 \pm 0.29$ & $24.50-25.00$ & 1.20 & $20.83 \pm 0.12$ & $20.70-20.90$ & 0.58 \\
Eichhornia natan & $23.67 \pm 0.58$ & $23.00-24.10$ & 2.5 & $24.20 \pm 0.10$ & $24.10-24.3$ & 0.41 \\
Nymphaea lotus & $15.50 \pm 0.10$ & $15.40-15.60$ & 0.70 & $15.27 \pm 0.08$ & $15.20-15.30$ & N.F \\
Azolla africana & $17.07 \pm 1.01$ & $16.50-18.00$ & 5.92 & N.F & 18.5 & N.F \\
Heteranthera califollia & $20.17 \pm 0.12$ & $20.10-20.30$ & 0.60 & $18.10 \pm 0.10$ & $18.00-18.20$ & 0.55 \\
Water lilly & $23.73 \pm 0.64$ & $23.00-24.20$ & 2.70 & $20.33 \pm 0.58$ & $20.00-21.00$ & 2.85 \\
Pistia stratiotes & $18.10 \pm 0.36$ & $17.80-18.50$ & 1.99 & $15.10 \pm 0.10$ & $15.00-15.20$ & 0.66 \\
Lemna spp & N.F & N.F & N.F & $15.33 \pm 0.15$ & $14.50-15.50$ & 0.98 \\
\hline
\end{tabular}

All values are expressed as mean \pm SD (Range) $C V, n=3, C . I=95 \%$, N.F $=$ Not Found.

Table 2. Shows the comparative volume of oxygen $(\mathrm{ml})$ evolved from hydrogen peroxide by unit weight of root tissue from different species of aquatic macrophytes.

\begin{tabular}{|c|c|c|c|c|c|c|}
\hline $\begin{array}{l}\text { Species of aquatic } \\
\text { macrophytes. }\end{array}$ & $\begin{array}{c}\text { Ethiope River } \\
\text { (station A) }\end{array}$ & $\begin{array}{c}\text { Range } \\
\text { Min-max. }\end{array}$ & $\begin{array}{c}\mathrm{CV} \\
\%\end{array}$ & $\begin{array}{c}\text { Ikpoba River } \\
\text { (Station B) }\end{array}$ & $\begin{array}{c}\text { Range } \\
\text { Min.-Max. }\end{array}$ & $\begin{array}{c}\mathrm{CV} \\
\%\end{array}$ \\
\hline Eichhornia crassipes & $15.80 \pm 0.20$ & $15.60-16.00$ & 1.27 & $14.78 \pm 0.06$ & $14.70-14.90$ & 0.41 \\
\hline Eichhornia natan & $16.67 \pm 0.58$ & $16.00-17.00$ & 3.48 & $16.78 \pm 0.08$ & $16.70-16.90$ & 0.48 \\
\hline Nymphaea lotus & $12.30 \pm 0.31$ & $13.00-14.00$ & 2.52 & $13.37 \pm 0.08$ & $13.00-13.40$ & 0.58 \\
\hline Azolla africana & $12.00 \pm 0.05$ & $11.50-12.50$ & 0.42 & N.F & N.F & N.F \\
\hline Heteranthera califollia & $12.70 \pm 1.21$ & $12.00-14.10$ & 9.53 & $14.37 \pm 0.56$ & $14.00-15.00$ & 3.90 \\
\hline Water lilly & $17.13 \pm 0.15$ & $17.00-17.30$ & 0.88 & $20.33 \pm 0.58$ & $20.00-21.00$ & 2.85 \\
\hline Pistia stratiotes & $13.80 \pm 0.49$ & $13.30-14.20$ & 3.55 & N.F & N.F & N.F \\
\hline Ceratophyllum spp & $13.43 \pm 0.51$ & $12.50-13.50$ & 3.80 & $17.10 \pm 0.12$ & $17.00-17.20$ & 0.70 \\
\hline
\end{tabular}

All values are expressed as mean \pm SD (Range), CV $, \mathrm{n}=3, \mathrm{C} . \mathrm{I}=95 \%, \mathrm{~N} . \mathrm{F}=$ Not Found. 
As shown in Table 3, since the calculated $\mathrm{H}$ value is less than the tabulated $\mathrm{H}$ value (critical $\mathrm{H} 0.05$ value), (i.e. $0.07<3.841$ ) hence, null hypothesis is accepted $(\mathrm{P}>0.05)$.

[17] reported the significant key role CAT activity plays in the stress acclimation process of species of $\mathrm{C}_{3}, \mathrm{C}_{4}$ and Crasulacean acid metabolism (CAM) plants.

Nifia lotus in leaf tissue of both stations ranged (15.20 - $15.60 \mathrm{ml})$. Nifia lotus had the mean leaf value of $15.50 \pm 0.10$ in the Ethiope River and $15.27 \pm 0.08$ in Ikpoba River (Table 1). The root tissue of Nifia lotus ranges from (13.00 - 14.00) respectively in both stations. The mean root value in Ethiope River recorded $12.30 \pm 0.31$ lower compared to the value recorded in Ikpoba River which had $13.37 \pm 0.08$. Nifia lotus is from the family Nympheaceae and some species of plant in different families have increase activities of catalase in their leaves and a decline of catalase activity in their roots which is in agreement with [18]. In wheat seedlings, of Poaceae family, catalase (CAT) activity enhanced in leaves and a decline in roots, showing a differential response under heavy metal pollutant stress.

Table 3. Shows the comparative volumes (ml) of oxygen evolved from hydrogen peroxide by unit weight of leaves and root tissues from different plant species of a quatic macro-phytes in the two different stations, are tested for their level of significance.

\begin{tabular}{cccc}
\hline $\begin{array}{c}\text { Ethiope River } \\
\text { Station (1) }\end{array}$ & $\begin{array}{c}\text { Ikpoba River } \\
\text { Station }(2)\end{array}$ & $\begin{array}{c}\text { Ranking of } \\
\text { Station }(1)\end{array}$ & $\begin{array}{c}\text { Ranking of } \\
\text { Station }(2)\end{array}$ \\
\hline 24.83 & 20.83 & 31 & 26 \\
23.67 & 24.20 & 28 & 30 \\
15.50 & 15.27 & 12 & 10 \\
17.07 & ---- & 16 & ---- \\
20.17 & 18.10 & 21.50 & 19.50 \\
20.17 & 20.33 & 21.50 & 23.50 \\
23.73 & 15.10 & 29 & 9 \\
18.10 & 15.33 & 19.50 & 11 \\
---- & 21.83 & ---- & 27 \\
20.67 & 14.78 & 25 & 8 \\
15.80 & 16.78 & 13 & 15 \\
16.67 & 13.37 & 14 & 4 \\
12.30 & ---- & 2 & ---- \\
12.00 & 14.37 & 1 & 7 \\
12.70 & 20.33 & 3 & 23.50 \\
17.13 & ---- & 18 & ---- \\
13.80 & 17.10 & 6 & ---- \\
13.43 & ---- & 5 & $\mathrm{R}_{2}=230.50$ \\
$\mathrm{n}_{1}=17$ & $\mathrm{n}_{2}=14$ & $\mathrm{R}_{1}=265.50$ & \\
\hline $11+14$ & & & \\
\hline
\end{tabular}

$\mathrm{n}_{1}+\mathrm{n}_{2}=17+14=31$. Number of occurrence in station $1, \mathrm{n}_{1}=17$, Number of occurrence in station $2, \mathrm{n}_{1}=$ 17 , Ranking of station $1,\left(R_{1}\right)$, and Ranking of station $2,\left(R_{2}\right)$ respectively. 
Azolla africana was only found in station 1, Ethiope River, the leaf tissue ranged $(16.50-18.00 \mathrm{ml})$. The mean leave value recorded was $17.07 \pm 1.01$. The root tissue ranged $(11.50-12.00 \mathrm{ml})$ and had root mean value of $12.00 \pm 0.05$. The catalase activity in the leaf tissue is higher compared to that of root tissue; the reason is as a result of the fact that the roots of a species of plant absorbs water more than the leaves, and if the aquatic environment is polluted, then the roots are affected mostly more than the leaves. Proteins structure and function also reveal decreased catalase (CAT) activity in roots more than the leaves among a range of other plant species [19]. The accumulation of hydrogen peroxide to a toxic level, cause oxidative stress to plants, degradation of enzyme by induced peroxisomal proteases may be another possible reason for the decline in root catalase activity. Similarly, manganese also showed a significant catalase activity reduction of pea seedlings.

Heteranthera califillia leaf tissue ranged $(18.00-20.30 \mathrm{ml})$ in both stations in Table 1. The mean leaf value recorded was $20.17 \pm 0.12$ in Ethiope River, and $18.10 \pm 0.10$ in Ikpoba River. The root tissue ranged (12.00 - $15.00 \mathrm{ml})$ in Table 2. The mean root values recorded in Ethiope and Ikpoba River respectively are $12.70 \pm 1.21$ and $14.37 \pm 0.56$, the mean root value in IKpoba River was higher compared to the value in Ethiope River. The decreased activity of catalase of some species of plant maybe resulted in the presence of physicochemical parameters of the Ikpoba River, which degrade the quality of the water as well as the levels of catalase activity in some of the plant species belonging to crassulacean acid metabolism (CAM). [20] did a similar work in Ikpoba River and their study focused on the physicochemical parameters from nearby industries as a major cause of the pollution that degrades the water quality. Heteranthera callifollia belongs to Pontederiaceae family.

Water Lilly is a flowering aquatic plant that is used to purify water, as well as their roots, could be a source of food for fishes and other aquatic creatures. It belongs to the Nymphaceae family. The leaf tissue of Water Lilly in both stations ranged from $20.00-24.20 \mathrm{ml}$. The activity and levels of catalase mean value recorded in Ethiope River is $23.73 \pm 0.64 \mathrm{ml}$, while Ikpoba River recorded $20.33 \pm$ $0.58 \mathrm{ml}$. The root tissue of Water lilly in both station ranged $(17.00-21.00 \mathrm{ml})$. The mean value of root tissue in Ethiope River was recorded $17.13 \pm 0.15 \mathrm{ml}$ and $20.33 \pm 0.58 \mathrm{ml}$ in Ikpoba River. The root tissue in Ikpoba River is higher than that of Ethiope River because of limited fecal pollutants that are absorbed by their roots; secondly, in most areas where samples were collected close to Ethiope Female Hostel (EFH), all the sewage systems are bad and the sludge is channeled to the River with lots of effluent sediment. The leaf tissue had a higher mean value because, during phosphorylation, transpiration, photorespiration and photosynthesis, the activities of gaseous exchange through stomata and lenticel take place in their leaves. Pistia statiotes Linn commonly known as water lettuce belongs to the family Araceae. It is a free-floating aquatic herb with thick, succulent leaves, profuse long underwater stolons and white unbranched fibrous 
rots that may sometimes attach to the bottom of shallow waters. It reproduces mainly vegetatively by buds and stolons. It rarely produces seeds. The activity of catalase effects on leaf tissue in both station ranged $(15.00-18.50 \mathrm{ml})$. The mean value of leaf tissue in the Ethiope River recorded $18.10 \pm 0.36 \mathrm{ml}$, and the root tissue value recorded in the same staion is $13.80 \pm 0.49 \mathrm{ml}$ while Ikpoba River recorded $15.10 \pm 0.10 \mathrm{ml}$ the mean value of leaf tissue, that of the root was not found as shown in Table 2 . The catalase activity value in leaf tissue of this plant species is higher in Ethiope River more than Ikpoba River, this may be a result of less or lack of industrial discharge pollutants in the Ethiope River compared to that of Ikpobal River that is surrounded by industries. Discharge of effluent pollutants into Ikpoba River from a faraway or nearby manufacturing factories sewage discharge could result to decrease level of catalase activity, often containing industrial wastes, discharges from animal rearing, fish farming and agriculture, seepage from domestic and industrial landfill sites and finally urban surface water run-off in Edo state. All these effects may contribute to what made the roots of this plant species to be affected because it has been tampered with by those discharges. Lemna species commonly known as Duckweed or Duck lens is aquatic macrophytes that have a short life cycle. It belongs to the family Lemnaceae. Lemna spp was only found in Ikpoba River (station 2). This plant species ranged from $(15.20-15.50 \mathrm{ml})$, the mean value of catalase in its leaf tissues recorded $15.33 \pm 0.15 \mathrm{ml}$, but the catalase activity in its root tissues was not recorded because it is a shrub. Their roots are very difficult to gather only their leaves.

\section{Conclusion}

Plants species of aquatic macrophytes responded to different levels of catalase enzyme activity. The leaf tissue of these plant species recorded higher catalase activity more than the root tissues. This is because plant roots positively respond to polluted water as well as chemical in the water body (hydrotropism and chemotropism) and leave negatively responces to river and chemical respectively. Though they play the role of detoxification of heavy metals, caused depletion of glutathione as a major antioxidant in plant cells. These plant species accumulate a high amount of heavy metals and however show a potential to be used as phytoremediator species in aquatic water bodies having moderate pollution of lead $(\mathrm{Pb})$. Catalase is an important antioxidant enzyme, which also plays a key role in plant organelles such as peroxisomes, mitochondria, cytosome and chloroplast, etc. of aquatic macrophytes. Plant species of aquatic macrophytes usually experience different stress conditions and a basic situation in most of their physiological challenges in the generation of harmful reactive oxygen species (ROS). To combat the damaging effects of ROS, plant species of aquatic macrophytes are equipped with a defense antioxidant system, which serves as defense mechanisms.

\section{Acknowledgements}

My profound gratitude and appreciation go to my supervisors Prof. (Mrs). B.N. 
ILOBA, Dr. Sese Owei Ekaye, whose direction, patience and constructive guidance combined with interest and encouragement led to the successful completion of this work. God bless all of you and your entire family. My thanks also go to the Head of Department, Prof. T.O.T. Imoobe, and other lecturers of this great Department of Animal and Environmental Biology, Faculty of Life Sciences, University of Benin, Benin-city, Nigeria. My inexpressible gratitude goes to my wife Mrs. Eunice I. O. Osaji and other members of my family, most especially my daddy and my mummy. I acknowledged my unforgettable coursemate as well as paper editor Mr. Samuel Akpogheneta, Prof. A.E. Ogbeibu, late Prof. J.M.O. Eze, and Prof. J.O. Olomukoro, other lecturers and students in the Department of Animal and Environmental Biology who in one way or the other contributed to facilitating the completion of this work.

\section{Conflicts of Interest}

The authors declare no conflicts of interest regarding the publication of this paper.

\section{References}

[1] Zhang, Y.D. and Barrette, S.C. (2010) Genetic Uniformity Characterizes the Invasive Spread of Water Hyacinth (Eichhornia crassipes), a Clonal Aquatic Plant. Molecular Ecology, 19, 1774-1786. https://doi.org/10.1111/j.1365-294X.2010.04609.x

[2] Sahelia, R.M.D. (2003) Catalase Enzymes on Plants and Animals. Washington University Press, Washington DC, 20-23.

[3] Gordon, U.R., and Randy, M.S. (2001) Principle of Botany. 4th Edition, MC Grand Hill, New York, 488-493.

[4] Chelikani, P., Fita, I. and Loewena, P.C. (2004) Diversity of Structures and Properties among Catalase Enzyme on Aquatic Macrophytes on Heavy Metals. Cellular and Molecular Life Sciences, 61, 192-208. https://doi.org/10.1007/s00018-003-3206-5

[5] Igbal, A., Yabuta, Y., Takeda, T., Nakano, Y. and Shigeoka, S. (2006) Hydroperoxide Reduction by Thioredoxin-Specific Glutathione Reductase of Excitation Energy Partitioning and Carbon Dioxide $\left(\mathrm{CO}_{2}\right)$ Fixation. Field Crops Research, 94, 165-175.

[6] Koepke, J.L., Nakrieko, K.A., Wood, C.S., Boucher, K.K., Terlecky, L.J., Walton, P.A. and Terlecky, S.R. (2007) Restoration Peroxisomal Catalase Import in a Model of Human Cellular Ageing. Traffic, 8, 1590-1600. https://doi.org/10.1111/j.1600-0854.2007.00633.x

[7] Osumo, W. (2001) Effects of Water Hyacinth on Water Quality of Winam Gulf, Lake Victoria Final Project 2001. http://unuftp.is/projoi/osumoPRF.Pdf

[8] Loncar, N. and Fraaije, M.W. (2015) Catalases as Biocatalysts in Technical Applications: Current State and Perspectives. Applied Microbiology and Biotechnology, 99, 3351-3357. https://doi.org/10.1007/s00253-015-6512-6

[9] Asada, K., Foyer, C.H. and Mullineaux, P.M. (1999) Production and Action of Reactive Oxygen Species in Photosynthetic Tissues. In: Causes of Photoxiclative Stress and Amelioration of Defense System in Plants, 2nd Edition, CRC Press, Boca Raton, 77-104. https://doi.org/10.1201/9781351070454-3

[10] Sharma, P., Jha, A.B., Dubey, R.S. and Pessarakli, M. (2012) Reactive Oxygen Spe- 
cies, Oxidative Damage, and Antioxidative Defense Mechanism in Plants under Stressful Conditions. Journal of Botany, 2012, Article ID: 217037. https://doi.org/10.1155/2012/217037

[11] Eze, J.M.O. and Dumbroff, E.B. (2008) A Comparison of the Bradford and Lawry Methods for the Analysis of Protein in Chlorophyllous Tissue. Canadian Journal of Botany, 60, 1046-1049. https://doi.org/10.1139/b82-133

[12] Ogbeibu, A.E. (2014) A Practical Approached to Research and Data Handling. Mindex Co Ltd, Benin, and Edo State, 114-117.

[13] Srivastava, S., Mishra, S., Baghel, S., Verma, P.K., et al. (2005) Nickel Phytoremediation Potential of Broad Bean, Vicia faba L., and Its Biochemical Responses. Bulletin of Environmental Contamination and Toxicology, 74, 715-724.

https://doi.org/10.1007/s00128-005-0641-z

[14] Akobundu, I.O. and Agyakwa, C.W. (1998) A Handbook of West African Weeds. International Institute of Tropical Agriculture by African Books Builders Ltd., Ibadan, 70-98.

[15] Wang, G.P. W., Hui, Z., Li, F., Zhao, M.R., Zhang, J. and Wang, W. (2010) Improvement of Heat and Drought Photosynthetic Tolerance in Wheat by Overaccumulation of Glycinebetaine. Plant Biotechnology Reports, 4, 213-222. https://doi.org/10.1007/s11816-010-0139-y

[16] Kaushal, J., Mehandia, S., Singh, G., Raina, A. and Arya, S.K. (2018) Catalase Enzyme: Application in Bioremediation and Food Industry. Biocatalysis and Agricultural Biotechnology, 16, 192-199. https://doi.org/10.1016/j.bcab.2018.07.035

[17] Gondim, F.A., Gomes-Filho, E., Costa, J.H., Mendes Alencar, N.L. and Prisco, J.T. (2012) Catalase Plays a Key Role in Salt Stress Acclimation Induced by Hydrogen Peroxide Pretreatment in Maize. Plant Physiology and Biochemistry, 56, 62-71. https://doi.org/10.1016/j.plaphy.2012.04.012

[18] Li, Y., Chen, L., Mu, J. and Zuo, J. (2013) LESION SIMULATING DISEASE1 Interacts with Catalases to Regulate Hypersensitive Cell Death in Arabidopsis. Plant Physiology, 163, 1059-1070. https://doi.org/10.1104/pp.113.225805

[19] Rodriguez-Serrano, L.A. and Sandalio, L.M. (2006) Cadmium Effect on Oxidative Metabolism of Pea (Pisum sativum L.) Roots. Imaging of Reactive Oxygen Species and Nitric Oxide Accumulation in Vivo. Plant, Cell \& Environment, 29, 1532-1544. https://doi.org/10.1111/j.1365-3040.2006.01531.x

[20] Ogbeibu, A.E. and Anozia, C.A. (2007) Impact of Dredging on Water Quality and Rotifers of Ikpoba River, Benin City, Nigeria. International Journal of Ecology and Environmental Sciences, 33, 293-300. 